\title{
Glucose Sensor Based on Glucose Oxidase Immobilized by Zirconium Phosphate
}

\author{
Sejin Park, ${ }^{*}, *$ Taek Dong Chung, ${ }^{* \dagger}$ Sun Kil Kang, ${ }^{* *}$ Ran-A Jeong, ${ }^{*}, * *$ Hankil Boo, ${ }^{*}, * *$ and \\ Hee Chan KIM**ं
}

*Department of Chemistry, Sungshin Women's University, 249-1, Dongsun-dong, Seongbuk-gu, Seoul 136-742, Korea

**Department of Biomedical Engineering, College of Medicine and Institute of Medical and

Biological Engineering, Medical Research Center, Seoul National University,

28 Yongon-dong, Chongno-ku, Seoul 110-744, Korea

\begin{abstract}
Amperometric glucose sensors were fabricated using glucose oxidase (GOx) entrapped in zirconium hydrogenphosphate $(\mathrm{ZrP})$, and their performance was evaluated. Reportedly, $\alpha-\mathrm{ZrP}$ is one of the candidates that are expected to improve the stability of enzymes immobilized on solid surfaces. ${ }^{1,2}$ We intercalated GOxs into $\mathrm{ZrP}$ (GOx/ZrP), cast the GOx/ZrP suspension in polyvinylalcohol on a platinum electrode, and dried it in a vacuum oven. The morphological layered structure was investigated by scanning electron microscopy. The enzymatic activities, which were determined by opencircuit potentiometric technique, reached the highest when GOxs were immobilized in $\mathrm{ZrP}$ at $c a$. $\mathrm{pH}$. In vitro tests showed good linear responses in the $0-25 \mathrm{mM}$ range and the sensitivity of $0.14 \mathrm{nA} \mathrm{mM}^{-1}$ at $0.4 \mathrm{~V} v s$. $\mathrm{Ag} / \mathrm{AgCl}$. The sensors, as made, were stable for more than 3 days within a limited deterioration.
\end{abstract}

(Received June 30, 2004; Accepted August 25, 2004)

The immobilization of enzymes into protective environments can be used to improve enzyme activity and selectivity in a desirable way. ${ }^{3}$ To date, a number of efforts have been made upon protective environments, such as polymers, sol-gels, surfactant films, and hydrogels, that can inhibit microbial degradation, hydrolysis, and deamidation, and can extend the useful lifetime of bound proteins while preserving their activities. $^{4-6}$ However, only a relatively small number of research groups have investigated the gallery of inorganic layered materials to find protective environments. Zirconium phosphate ( $\mathrm{ZrP})$, layered double hydroxide (LDH), and montmorillonite are representative examples that have been studied because of their ion-exchange capabilities and intercalation properties. They are thermally stable and chemically inert in neutral solution, so that immobilized enzymes can be provided with favorable environments for preserving their activities.

The layers of $\mathrm{ZrP}$ bear anionic surfaces (up to one negative charge per phosphate) that contribute to make themselves bind together. Reportedly, the hydrophilic nature of $\mathrm{ZrP}$ can play an important role in stabilizing surface-bound proteins., ${ }^{1,2,7}$ According to Kumar et al., the intercalation of proteins into the layers is a function of the binding constants and pI values. Proteins immobilized in $\alpha$-ZrP show no detectable structural changes, and retain their activities. ${ }^{1}$ The loose packing of GOx was ascribed to the low binding constant and low pI (4.0) value of GOx.

In the case of montmorillonite, significant research has been conducted, mostly in view of comparison with $\mathrm{ZrP}$ and $\mathrm{LDH}$. The main issue concerning montmorillonite study is the electron transfer process of the redox protein incorporated into the

† To whom correspondence should be addressed.

E-mail: chembud@sungshin.ac.kr; hckim@snu.ac.kr montmorillonite-modified membrane (not into its interlayer gallery as yet). ${ }^{8-10}$ The hemoglobin incorporated in such a montmorillonite-modified pyrolytic graphite electrode shows well-defined peak currents, ${ }^{8}$ which are not observed at bare pyrolytic graphite electrodes immersed in a hemoglobin solution (e.g., $0.1 \mathrm{mM}){ }^{8,11,12}$ Furthermore, the hemoglobin sustains most of its native structure in montmorillonite film. ${ }^{8}$ In spite of many studies that addressed direct electron transfer to and from proteins in montmorillonite, the U.S. patent by Shen $e t$ $a l .{ }^{13}$ is the only report on the intercalation of enzymes into a montmorillonite to date.

On the other hand, the unique anion-exchange capability of LDH meets the requirements of inorganic materials for encapsulating functional biomolecules with negative charge in aqueous media. Such biomolecules can be incorporated between hydroxide layers by simple ion-exchange to form LDH/biomolecule composites. ${ }^{14,15}$ For instance, the hydroxide layers can be a reservoir to protect the intercalated DNA from DNase degradation. ${ }^{15}$

The present paper is the first report on the application of GOx immobilized in $\mathrm{ZrP}$ for an amperometric glucose sensor. Although Ruan et al. ${ }^{16}$ reported on a ZrP-based enzyme electrode with peroxidase and a mediator embedded in $\mathrm{ZrP}$, there has been no report on glucose sensors based on GOx embedded in $\mathrm{ZrP}$ to our best knowledge. In this study, GOx was intercalated in $\mathrm{ZrP}$ according to the method described by Kumar et al. and GOx in a $\mathrm{ZrP}(\mathrm{GOx} / \mathrm{ZrP})$ nano-composite functioned as a signal transducer for an enzymatic amperometric glucose sensor.

\section{Experimental}

\section{Reagents}

Zirconium hydrogen phosphate $\left(\mathrm{Zr}\left(\mathrm{HPO}_{4}\right)_{2}\right.$, Aldrich 46432-6), 
Table 1 Compositions of the GOx stock solutions

\begin{tabular}{cccccc}
\hline $\begin{array}{c}\mathrm{GOx} \\
\text { solution }\end{array}$ & $\begin{array}{c}\mathrm{H}_{3} \mathrm{PO}_{4} / \\
\mathrm{mM}\end{array}$ & $\begin{array}{c}\mathrm{KH}_{2} \mathrm{PO}_{4} / \\
\mathrm{mM}\end{array}$ & $\begin{array}{c}\mathrm{K}_{2} \mathrm{HPO}_{4} / \\
\mathrm{mM}\end{array}$ & $\begin{array}{c}\mathrm{GOx} / \\
\mathrm{mg} \mathrm{mL}^{-1}\end{array}$ & $\mathrm{pH}$ \\
\hline $\mathbf{1}$ & - & 5 & 5 & 2 & 6.9 \\
$\mathbf{2}$ & - & 10 & - & 2 & 4.9 \\
$\mathbf{3}$ & 0.9 & 9.1 & - & 2 & 3.2 \\
\hline
\end{tabular}

All the GOx solutions contain $1 \mathrm{mM} \mathrm{CaCl}_{2}$.

glucose oxidase (GOx, E.C. 1.1.3.4, high purity, 15000 - 25000 units/g, type II-S, Aspergillus niger, Sigma), tetrabutylammonium hydroxide (Aldrich 17878-0, $40 \mathrm{wt} \%$ in water), peroxidase (E.C. 1.11.1.7, 1520 units/g, type VI-A, Horseradish, Sigma), potassium ferricyanide (AJAXS Chemicals), potassium ferrocyanide (Aldrich), polyvinyl alcohol (PVA, Aldrich), and D-glucose (Aldrich) were used without purification.

\section{Instruments}

The absorbance was measured with an UV-visible spectrophotometer (Hewlett-Packard, 5890). Scanning electron microscopic (SEM) images were obtained using Model JSM 840-A (JEOL). Electrochemical experiments were performed with an electrochemical analyzer (Model CH660, $\mathrm{CH}$ Instruments Inc., Austin, TX 78733). $\mathrm{Ag} / \mathrm{AgCl}(3 \mathrm{M} \mathrm{KCl})$ and platinum wire were used as reference and counter electrodes, respectively. A Pt rod electrode $\left(0.031 \mathrm{~cm}^{2}\right)$ was the substrate electrode for the GOx/ZrP enzyme layer. A glassy carbon rod electrode was employed as the working electrode for potentiometric experimentation. A Model cDAQ-1604 multichannel potentiostat (ELBIO Co., Seoul) was used to investigate the reproducibility of sensors simultaneously. The acquired data were transferred to a personal computer using USB protocol. The control and data-acquisition programs were written in LabVIEW (National Instrument, version 5.0).

\section{Intercalation of GOx in $\mathrm{ZrP}(\mathrm{GOx} / \mathrm{ZrP})$}

GOx/ZrP samples were prepared by adopting the method described by Kumar et al. with a few modifications. ${ }^{1,7}$ A $0.2 \mathrm{~g}$ volume of $\mathrm{Zr}\left(\mathrm{HPO}_{4}\right)_{2}$ in $10 \mathrm{~mL}$ of distilled water was mixed with stoichiometric amounts $(0.46 \mathrm{~g})$ of tetrabutylammonium hydroxide (40 wt $\%$ in water) to make the exfoliated $\mathrm{Zr}\left(\mathrm{HPO}_{4}\right)_{2}$ (2\%) suspensions. The resulting solution was subsequently sonicated and allowed to rest for $1 \mathrm{~h}$. A stock solution of GOx was mixed with exfoliated $\operatorname{ZrP}(2 \mathrm{wt} \%)$ in a 3:1 volume ratio. A few GOx stock solutions at different $\mathrm{pH}$ values were tried to probe the effect of the $\mathrm{pH}$ on GOx intercalation (Table 1). The mixtures were equilibrated for $22 \mathrm{~h}\left(4^{\circ} \mathrm{C}\right)$ and filtered to collect immobilized GOxs. The amount of intercalated GOx was determined by comparing the absorbance $(278 \mathrm{~nm})$ of the filtrate solution with that of the GOx solution before it underwent intercalation. The collected $\mathrm{GOx} / \mathrm{ZrP}$ was dried in a vacuum oven $\left(25^{\circ} \mathrm{C}\right)$ differing from the lyophilizing process performed by Kumar et al. The resulting GOx/ZrPs were named as GOx/ZrP1, GOx/ZrP2, and GOx/ZrP3 according to the GOx stock solution used i.e., 1, 2 or $\mathbf{3}$. GOx/ZrPs were stored under $0^{\circ} \mathrm{C}$ when they were not used.

\section{GOx/ZrP film on a platinum electrode (Pt/GOx/ZrP)}

$\mathrm{GOx} / \mathrm{ZrP}$ powders $(5 \mathrm{mg}$ ) were dispersed in $0.5 \mathrm{~mL}$ of a PVA solution (1\%) and sonicated for ca. $5 \mathrm{~min}$. The mixture $(2.5$ $\mu \mathrm{L} / 3 \mathrm{~mm}^{2}$ ) was cast on a platinum rod electrode, and dried in a vacuum oven at $25^{\circ} \mathrm{C}$.
Table 2 Amounts and activities of GOx immobilized on $\mathrm{ZrP}$

\begin{tabular}{ccc}
\hline & $\begin{array}{c}\text { GOx content } \\
\text { in ZrP, \% }\end{array}$ & Slope/mol s \\
\hline GOx/ZrP1 & 3.3 & $2.13 \times 10^{-12}$ \\
GOx/ZrP2 & 3.0 & $4.01 \times 10^{-11}$ \\
GOx/ZrP3 & 0.6 & - \\
\hline
\end{tabular}

Potentiometric determination of GOx/ZrP enzymatic activity

The GOx/ZrP (20 mg), as prepared, was suspended in $5.0 \mathrm{~mL}$ of a PBS solution containing horseradish peroxide (HRP, $1 \mathrm{mg}$ ), $\mathrm{Fe}(\mathrm{CN})_{6}{ }^{4-}$, and $\mathrm{Fe}(\mathrm{CN})_{6}{ }^{3-}$. The total amount of $\mathrm{Fe}(\mathrm{CN})_{6}{ }^{4-}$ and $\mathrm{Fe}(\mathrm{CN})_{6}{ }^{3-}$ was $1.0 \mu \mathrm{mol}$. The open circuit potential was measured using a 3-electrode system with a glassy carbon working electrode, a platinum wire counter electrode, and a $\mathrm{Ag} / \mathrm{AgCl}$ reference electrode $(3 \mathrm{M} \mathrm{KCl})$ immersed in the stirred solution. After the potential became stabilized, glucose (20 $\mathrm{mM}$ ) was added, and the change in the potential was monitored.

\section{In vitro evaluation of the sensor}

Experiments were performed in $0.1 \mathrm{M}$ phosphate buffered saline (PBS) solution containing a $0.15 \mathrm{M} \mathrm{NaCl}$ and $0.1 \mathrm{~g} / \mathrm{L}$ $\mathrm{NaN}_{3}$, and in a temperature-controlled cell containing $10 \mathrm{~mL}$ of

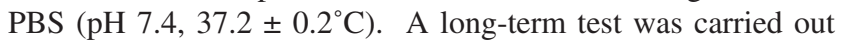
with a glucose sensor, which had been stored as dried in air $\left(25^{\circ} \mathrm{C}\right)$ between consecutive measurements.

\section{Results and Discussion}

\section{Intercalation of $G O x$ in $\mathrm{ZrP}$}

Mallouk et al. studied the $\mathrm{pH}$ effect on the intercalation of the tetrabutylammonium (TBA) ion. ${ }^{17}$ According to their data, tetrabutylammonium ions were not intercalated into $\mathrm{ZrP}$ at acidic condition. They reported that intercalation occurred above $\mathrm{pH} \quad 3.2$ to result in the compound $(\mathrm{TBA})_{\mathrm{x}} \mathrm{Zr}\left(\mathrm{HPO}_{4}\right)_{2-\mathrm{x}}\left(\mathrm{PO}_{4}\right)_{\mathrm{x}}$, and the amount of tetrabutylammonium ions intercalated, $x$, was proportional to the $\mathrm{pH}$. The stoichiometric value of $x$ was estimated to be 0.2 at $\mathrm{pH} 4.9$ and 0.6 at $\mathrm{pH} 6.9 .{ }^{17}$ When $\mathrm{pH}$ reached 8.4, the $x$ value became 0.7 and ZrP layers were fully exfoliated. ${ }^{17}$ Thus, it is hardly believed that GOx is intercalated into $\mathrm{ZrP}$ with assistance of tetrabutylammonium ion in GOx stock solution 3 (pH 3.2). The intercalation of GOx is expected to be driven by preintercalated media of $\mathrm{pH} 4.9$ and 6.9.

The amount of GOx intercalated in $\mathrm{ZrP}$ was determined using UV-visible spectrophotometry. The absorbance at $278 \mathrm{~nm}$ let us calculate the free-GOx concentration. Upon intercalation for $22 \mathrm{~h}$ at $4^{\circ} \mathrm{C}$, the ratios of intercalated GOx to total one were $11 \%(\mathrm{pH} 6.9, \mathrm{GOx} / \mathrm{ZrP1}), 10 \%(\mathrm{pH} 4.9, \mathrm{GOx} / \mathrm{ZrP2})$, and $2 \%$ $(\mathrm{pH} 3.2, \mathrm{GOx} / \mathrm{ZrP3})$. Table 2 shows that GOx contents in GOx/ZrPs are $3.3 \%$ (GOx/ZrP1), 3.0\% (GOx/ZrP2), and 0.6\% $(\mathrm{GOx} / \mathrm{ZrP3})$. More GOxs were intercalated at higher $\mathrm{pH}$ in spite of the electrostatic repulsion between negative charges of GOx $(\mathrm{pI}=4.0)$ and $\mathrm{ZrP}$. This implies that the electrostatic interaction between $\mathrm{ZrP}$ and GOx is not the only factor that affects on the intercalation process.

\section{Construction of enzyme electrodes}

The SEM image shown in Fig. 1(a) shows the morphology of the prepared GOx/ZrP, and Figs. 1(b) and (c) display the morphology of the GOx/ZrP layer coated with PVA as a binder. GOx/ZrP particles agglomerated into larger ones by PVA. Due to the binding role of PVA, the formed GOx/ZrP layer was 
(a)

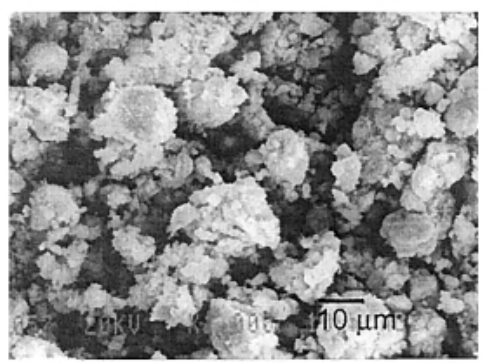

(b)

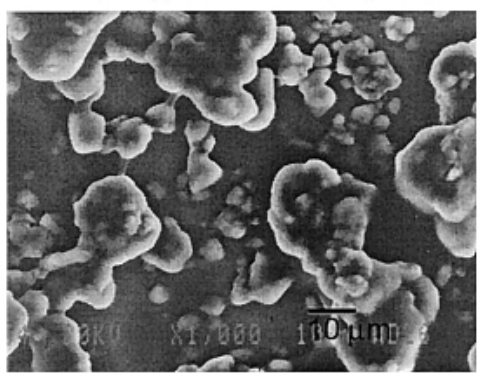

(c)

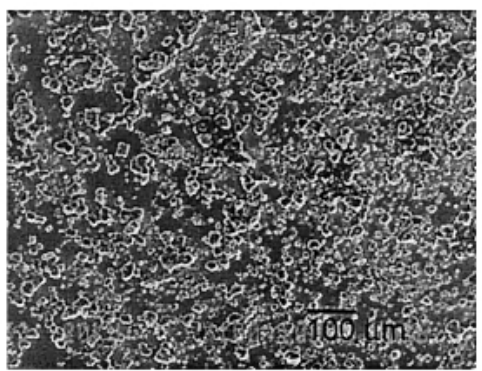

Fig. 1 SEM image of GOx/ZrP particles (a) and GOx/ZrP layer deposited with PVA (b, c).

sufficiently firm to hold out successive long-term activity test. Figure 2 shows a sketch of the enzyme layer of the constructed sensor based on a SEM image. GOx/ZrP particles are bound to the Pt surface with PVA. Glucose is oxidized by the GOx immobilized in the $\mathrm{ZrP}$, and the hydrogen peroxide produced is re-oxidized on the Pt surface to produce an oxidative catalytic current

\section{Enzyme activity of $G O x / \mathrm{ZrP}$}

The potentiometric method gave the activities of GOx/ZrPs prepared at different pH's. Instead of the conventional spectrophotometric method, we developed and adopted an electrochemical method to investigate the activity of GOx. The potentiometric method is free from the systematic error of the spectrophotometric one owing to the light scattering of inhomogeneity of the suspended $\mathrm{ZrP}$ powders. In this measurement, zero current potentials were measured as the GOx/ZrPs reacted with glucose in a solution containing ferricyanide, ferrocyanide, and HRP. Ferrocyanide was oxidized into ferricyanide and the potential of working electrode varied according to the Nerntian equation (Eq. (1)), as GOx/ZrP continued to maintain its enzymatic activity, as Scheme 1.

$$
E-E_{0}=-(0.05916 / n) \log \left(\left[\mathrm{Fe}(\mathrm{CN})_{6}{ }^{4-}\right] /\left[\mathrm{Fe}(\mathrm{CN})_{6}{ }^{3-}\right]\right)
$$

Figure 3(a) shows that the potential change of GOx/ZrP2 upon an addition of glucose agrees with what expected. Figure 3(b) displays the quantitative change of ferrocyanide to ferricyanide, which can be calculated from the difference between the

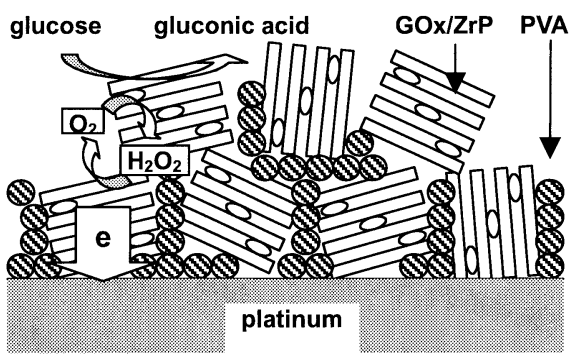

Fig. 2 Schematic sketch of the Pt/GOx/ZrP layer and its operation.
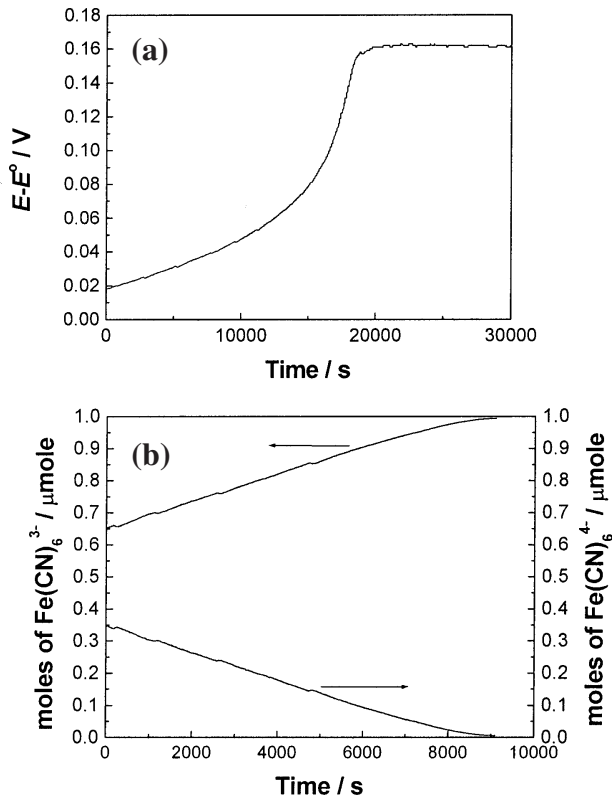

Fig. 3 Time profile of (a) the potential difference measured with GOx/ZrP2, and (b) ferricyanide and ferrocyanide amounts calculated from the change in potential.

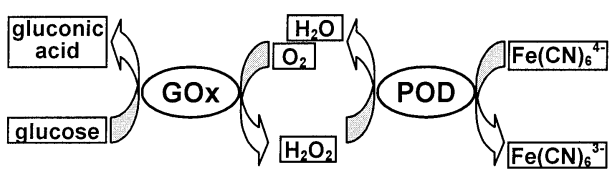

Scheme 1 Reactions during the potentiometric activity test

measured potential $(E)$ and the standard potential $\left(E^{0}\right)$, using Eq. (1). $E^{0}$ was determined to be $0.206 \mathrm{~V} v s . \mathrm{Ag} / \mathrm{AgCl}$ in a blank solution containing equimolar ferricyanide and ferrocyanide and $\mathrm{ZrP}$ instead of GOx/ZrP. The time profiles in Fig. 3(b) reveal a linear increase in ferricyanide and a decrease in ferrocyanide. The rate of ferrocyanide oxidation does not depend on the total concentration of ferricyanide and ferrocyanide. With the excess presence of HRP, this implies that the enzyme activity controls the overall reaction rate. Consequently it is believed that the slope of the linear part delivers information on the enzyme activity of GOx/ZrP.

The potentiometric activity test was performed with GOx/ZrP1 and GOx/ZrP2. The slopes are listed in Table 2. It is evident that $\mathrm{GOx} / \mathrm{ZrP2}$ exhibits much higher enzyme activity, although there is only a slight difference in the amount of GOx intercalated. Supposedly, the high activity of the GOx/ZrP2 

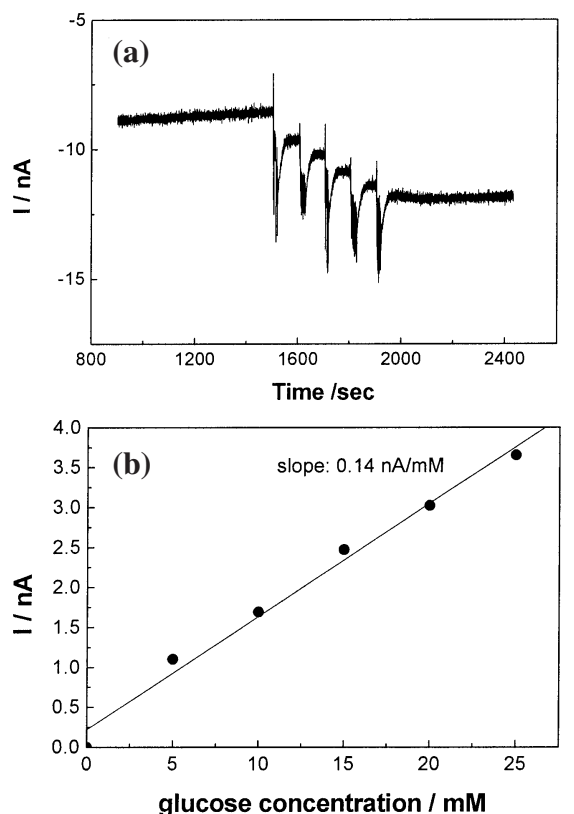

Fig. 4 (a) Responses of $\mathrm{Pt} / \mathrm{GOx} / \mathrm{ZrP2}\left(0.031 \mathrm{~cm}^{2}\right)$ to increments of the glucose concentration, and (b) calibration curve.

stems from the higher stability of GOx during intercalation. $\mathrm{GOx} / \mathrm{ZrP} 2$ was prepared at $\mathrm{pH} 4.9$, and literature says that GOx is most stable around this $\mathrm{pH} .{ }^{18}$ The enzyme activity loss during the intercalation reaction possibly affects the long reaction time. It is reasonable that the intercalation process near $\mathrm{pH} 5$ would minimize the activity loss more than those at other $\mathrm{pH}$ conditions.

\section{Sensor activity}

Glucose sensors, which were constructed with GOx/ZrP2, gave higher amperometric responses. Figure 4 shows the response of such a sensor to glucose in PBS solution. The observed sensitivity was $0.14 \mathrm{nA} \mathrm{mM}{ }^{-1}$, and the sensor maintained a linear response up to $25 \mathrm{mM}$, which covers the clinically meaningful glucose level range. Thus, the working range of the GOx/ZrP layered sensor is wide enough in the glucose range for practical monitoring.

\section{Stability}

Figure 5 shows the result of a long-term test using a glucose sensor with a GOx/ZrP2 layer. The sensor was stored under a dried condition (air, $25^{\circ} \mathrm{C}$ ) after each measurement, and was repeatedly used for the next measurement. The sensor signal was alive with a sensitivity of about $60 \%$ of the initial one after 3 days.

\section{Conclusion}

The enzymatic activity of GOx/ZrP depends on the $\mathrm{pH}$ of the solution used in the preparation. The optimal $\mathrm{pH}$ was found to be $c a$. 5, at which GOx is stable. Glucose sensors with $\mathrm{GOx} / \mathrm{ZrP}$ enzyme layers are not excellent in terms of sensitivity because only a small amount of GOx is immobilized. Thus, the detection limit of $c a .5 \mathrm{mM}$, based on signal-to-noise ratio of 2 , is poor. Moreover, the sensor maintains $60 \%$ of its initial sensitivity after 3 days in air at room temperature.

The sensor demonstrated in the present study was not equipped with a permselective membrane to reject interfering

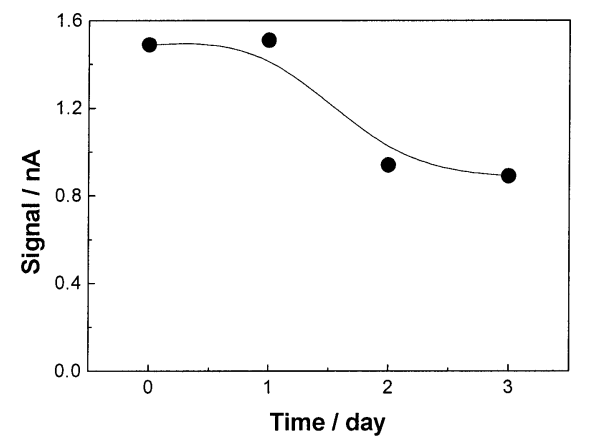

Fig. 5 Long-term test with $\mathrm{Pt} / \mathrm{GOx} / \mathrm{ZrP2}$. The signals were measured for $5 \mathrm{mM}$ glucose.

materials, such as ascorbic acid or uric acid. Further improvement for the glucose sensor with GOx/ZrP is required in terms of selectivity as well as sensitivity.

\section{Acknowledgements}

This work was supported by Korea Research Foundation Grant (KRF-2002-003-C00088).

\section{References}

1. C. V. Kumar and A. Chaudhari, J. Am. Chem. Soc., 2000, 122,830 .

2. C. V. Kumar and A. Chaudhari, Microporous Mesoporous Mat., 2001, 47, 407.

3. T. A. Horbett and J. L. Brash (ed.), in "Proteins at Interfaces II. Fundamental and Applications", 1995, American Chemical Society, Washington D.C.

4. J. Fang and C. M. Knobler, Langmuir, 1996, 12, 1368.

5. M. Mrkisch, G. B. Sigal, and G. M. Whitesides, Langmuir, 1995, 11, 4383.

6. J. K. Kennedy and C. A. White, in "Handbook of Enzyme Biotechnology", ed. A. Wieman, 1985, Ellis Horwood Ltd., Chichestor, 147.

7. C. V. Kumar and G. L. McLendon, Chem. Mater., 1997, 9, 863.

8. C. Fan, Y. Zhuang, G. Li, J. Zhu, and D. Zhu, Electroanalysis, 2000, 12, 14.

9. C. Lei and J. Deng, Anal. Chem., 1996, 68, 3344.

10. C. Lei, F. Lisdat, U. Wollwnberger, and F. W. Scheller, Electroanalysis, 1999, 11, 274.

11. A.-E. F. Nassar and J. F. Rusling, J. Am. Chem. Soc., 1996, $118,3043$.

12. A.-E. F. Nassar, W. S. Willis, and J. F. Rusling, Anal. Chem., 1995, 67, 2386.

13. S. Shen, A.-F. Hsu, T. A. Foglia, and S.-I. Tu, U. S. Patent, 2001, 6180378.

14. J. H. Choy, S. Y. Kwak, J. S. Park, Y. J. Jeong, and J. Portier, J. Am. Chem. Soc., 1999, 121, 1399.

15. J. H. Choy, S. Y. Kwak, Y. J. Jeong, and J. S. Park, Angew. Chem. Int. Ed., 2000, 39, 4041.

16. C. M. Ruan, F. Yang, J. S. Xu, C. H. Lei, and J. Q. Deng, Electroanalysis, 1997, 9, 1180.

17. D. M. Kaschak, S. A. Johnson, D. E. Hooks, H.-N. Kim, M. D. Ward, and T. E. Mallouk, J. Am. Chem. Soc., 1998, 120, 10887.

18. R. Wilson and A. P. F. Turner, Biosens. Bioelecron., 1992, 7, 165 . 